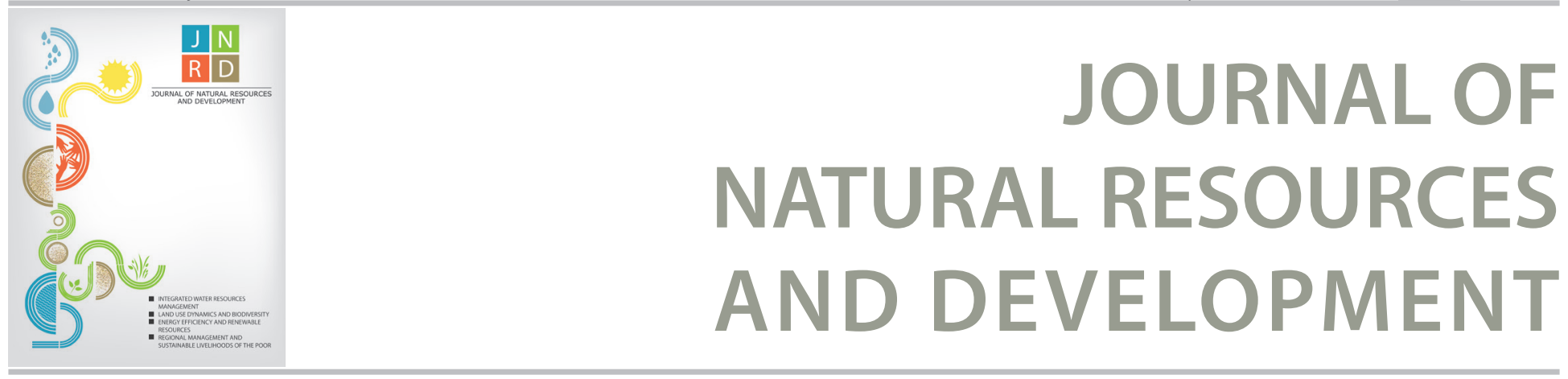

Research article

\title{
Trust and Rural Enterprise in the Trade Activities of Small-Scale Fisheries: Lessons Learned From
}

\section{Pangandaran, Indonesia}

\author{
Hafidz Wibisono ${ }^{\text {a*}}$, Andi Abdul Manaf a \\ a The authors are with the Faculty of Geography, Universitas Gadjah Mada, Skip Utara Jln Kaliurang Bulaksumur, Yogyakarta 55281, Indonesia
}

* Corresponding author: hafidzwibisono@ugm.ac.id

\section{Article history}

Received 12/02/2018

Accepted 11/05/2018

Published 17/05/2018

\section{Keywords}

Rural enterprise

Fisheries

Trust

Middlemen

Economics

\section{Abstract}

This paper explores the approach used by fisheries-related stakeholders to break the complex relationship between fishermen and middlemen in the fishing village of Pangandaran, West Java, Indonesia. This location was selected because the fisheries trade there has been institutionalized by the presence of rural enterprise. This is unusual, especially in traditional small-scale fisheries where trade is governed by middlemen. The information was obtained by interviewing key stakeholders from various parties and combining this with relevant secondary data. The main argument is that formalizing the fisheries market is not as simple as implementing technical regulations. There are non-technical factors that affect the entire process. The findings indicate that trust is the important variable that catalyzes the process and binds stakeholders in certain trading mechanisms. Furthermore, this situation is very helpful to divert the fishermen from patron-client relationships that are often unfavorable in the long term.

(c) 2018 This is an open access article under the CC BY-NC-ND license (http://creativecommons.org/licenses/bync-nd/4.0/).

\section{Introduction}

Discussions regarding fisheries_especially small-scale fisheries-are not always related to the amount of fish production and should also address social and economic aspects. Ironically, in many cases, an abundance of fisheries resources does not guarantee a fishermen's welfare. Most of the research conducted in developing countries in the last two decades has tended to emphasize the close relation between small-scale fishermen and issues of poverty and marginalization [1] In some Southeast-Asian and African countries such as Malaysia [2] Indonesia [3], Philippines [4], Nigeria [5], Sri Lanka [6], Ghana [7] Kenya and Zanzibar [8], small-scale fishermen are characterized by 
low education which leads to a lack of access to alternative sources of income. In other words, for them, fishing is their last resort occupation. In addition, the fishermen also have to deal with overfishing issues due to the increasing number of fishermen. The situation is worsened by ineffective fisheries management which leads to the existence of informal traders (middlemen) who often limit fishermen's access to the market by forcing them to sell their catches to the middlemen [8]-[12].

In Indonesia, around one percent of households depend on the fisheries sector as their livelihood. Most of them are small-scale fishermen who use simple, traditional boat/fishing gear and who depend on fishing as their only source of income [13]. This type of fishermen account for around 80 percent of Indonesian fish production (Indonesia Central Bureau of Statistics). Despite their enormous contributions, their average income is only 737,030 Rupiahs or 54.5 USD per month (Indonesia Central Bureau of Statistics). This data is reinforced by a study from Ministry of Marine Affairs and Fisheries of the Republic of Indonesia in 2014, which shows that $25 \%$ or around 7.9 million people from the Indonesian poor community was located in coastal areas. This is in contrast to the scale of fish production in Indonesia which reached 6.037.654 tons. in 2014.

Despite the fact that relationship between fishermen and poverty is a multidimensional issue, this paper focuses on the fishermenmiddlemen relationship as one of the common problems in Indonesian fishermen communities, later exploring how to deal with these issues. Using a case study approach, this paper aims to understand the fisheries market management process in the Pangandaran District, West Java Province, as a best practice on implementing regulation to terminate the negative links between fishermen and middlemen. In this area the average income of small-scale fishermen is about $1,200,000$ rupiah or 86.58 USD per month [14], [15], almost $60 \%$ more than the average fisherman's income in Indonesia. Rural enterprise plays a significant role in managing fish sales and controlling fish prices in Pangandaran. With a certain mechanism and approach, rural enterprise has succeeded in encouraging all stakeholders in the fisheries market to follow the regulations, including the middlemen who often disobey market regulations.

This research is mostly a qualitative research. The information was obtained by interviewing several stakeholders related to the issues. Interviewees are determined by identifying the parties involved in fisheries trade activities, such as the government, the fishermen and the local organizations. The number of interviewees was increased due to further identification through snowball sampling. To avoid oversimplification, triangulation was conducted when collecting and analyzing the data.

The empirical results of the research show that there are noncalculable and even personal variables which catalyze the process. These variables are necessary in binding the stakeholders in a formal trading mechanism. However, this paper does not provide a "one for all" solution for the particular problems, but highlights the factors and methods which are necessary in dealing with the generic problem, specifically in developing countries.

\section{Fisheries and Middlemen: Indonesian Context Overview}

Various studies have discussed the middleman's role in the fisheries market, mostly in developing countries [8]-[11], [16]. In general, the existence of middlemen is like two sides of a coin. On one side, the middlemen effectively link market demands, from areas such as industries or tourism, with small-scale fishermen, this is beneficial in opening market access for the fishermen [8], [16]. On the other side, the middlemen also dominate the market. [9], [11]. Even in most cases this circumstance allow middlemen to determine the price of fish and create a situation where the middlemen are the ones who most benefit [11]. In order to respond to these circumstances, balancing the exploitative and facilitative role of middlemen is the most necessary solution, but it is not easy due to the socio-economic complexity [17]. In Indonesia, middlemen and fishermen are inseparable. Cahaya [9] estimated that around $80 \%$ of Indonesian fishermen are attached to middlemen and most of them are small-scale fishermen who often lack capital even for their daily fishing activities. This condition is used by middlemen to provide capital loans to the fishermen, with various terms which are approved through informal oral agreements [8], [18]. The main condition imposed by the middlemen is an agreement to sell the catch at determined price. The domination of middlemen in fisheries trading activities is mostly caused by the absence of an auction mechanism or the abandonment of fish auctions due to the absence of an institution's power in dealing with the middlemen [19].

This circumstance is detrimental to the fishermen for at least three reasons. First, the middlemen often set a strangling price which is below the market price. Second, there are no possibilities for fishermen to expand their market-at least to find better opportunities-because market access and information is restricted by the middlemen [8], [11]. Third, fishermen will always depend on the loan provided by the middlemen, although this has short-term benefits, it has no longterm sustainability for the fishermen's income [8]. This is exacerbated by the low price set by the middlemen, making it difficult for the fishermen to repay their loans, in other words the fishermen will continue to be tied to their debt with the middlemen.

As well as in other countries, middlemen not only have a relationship with fishermen, but also the market [8], [16]. The need to fulfil market demand is used by the middlemen to take a role. They usually act as a market supplier by collecting fish from different fishermen. Middlemen usually have a relationship with many fishermen in order to meet their demand. There are two types of middlemen based on their role in intermediating between the market and the fishermen. First, the local middlemen. Local middlemen are people or groups of intermediaries who interact directly with the fishermen to obtain the catches. They often act as an agent for larger collectors. Local middlemen usually operate only in certain areas such as districts or specific fishing ports. Second, the bigger middlemen, who are larger middlemen with a direct relationship with the market on various scales. Bigger middlemen usually have many agents in various areas who help them collect the catches due to large demand from the market. Unlike the relationship between fishermen and local middlemen, which often tends to be a closed patron-client system, the relationship between local middlemen and bigger middlemen 
mostly takes the form of an open system. It means that there is no particular tie between the local middlemen and the bigger middlemen and competition among local middlemen is more common at this level [20]. A simplified explanation of the middlemen relationship with other stakeholders is shown in Figure 1.

It can be seen that the middlemen play an important role in channeling the market to the fishermen. This paper focuses on the relationship between fishermen and local middlemen which is not only an economic relationship but also has socio-cultural aspects as described in the previous paragraph.

\section{Dealing with Middlemen: Lessons Learned from Pangandaran}

\subsection{Location overview}

Pangandaran is the name of three different territorial units: regency, district, and village. However, this study takes place in the Pangandaran district which is located in the Pangandaran Regency, West Java Province (see Figure 2). The location was selected as it is the territory of KUD Minasari, a rural enterprise which is engaged in the fisheries sector. KUD Minasari was chosen for its success in minimizing informal trading involving middlemen. This area is a traditional fishing village and is also a famous tourism destination. The principal livelihoods are small-scale traditional fisheries and tourism services and goods. The fisheries and tourism activities are interconnected to each other [21]. Tourism helps to increase local demand-and of course to increase fish prices-due to tourists' demand for seafood, especially in high season.

The small-scale fisheries mentioned above are composed of traditional fishermen operating small low-tech boats of 2-3 people in their daily fishing activities with a fishing duration of 6-8 hours. There is no particular species caught in Pangandaran, but the majority of fish are small pelagic species and some species of demersal fish. Fish are caught with low-tech fishing gear such as gill nets, trammel nets, seines, and small trawls. Catches are also landed in a mediumsized landing site with a simple cooling process. Fish production in Pangandaran often fluctuates during the year. In some months, fish production can rise dramatically and can also fall due to weather and climate conditions. According to Figure 3, fish production often rises to its peak from August to November and slightly decreases from April to July. Data from 2013 and 2014 show similar results.

\subsection{The rural enterprise}

KUD Minasari [Rural enterprise in Pangandaran] was established in 1962 with the name of marine fisheries cooperative-"Koperasi Perikanan Laut [KPL]" in Indonesian. This was motivated by the desire of the fishermen to solve their marketing problem-at that time, the majority of fishermen were bound to middlemen [22]. It experienced several phases before becoming an authorized institution trusted by various stakeholders to manage the fish trade in the district. A brief timeline of KUD Minasari from 1962 until now in developing the fishing trade in the Pangandaran District can be seen in Figure 4.

At the beginning of its formation, the rural enterprise was a place to store funds collected from the fishermen through their profit contributions. The collected funds were used by the fishermen who needed cash for their fishing activities as loans. This method gradually succeeded in providing funds and accommodation for the fishermen. It also gave the fishermen a bargaining power to sell their catches at a better price. The coverage area of the cooperative was only in the coastal area of Pangandaran. The coverage area was expanded along with the business expansion and increases in the number of members

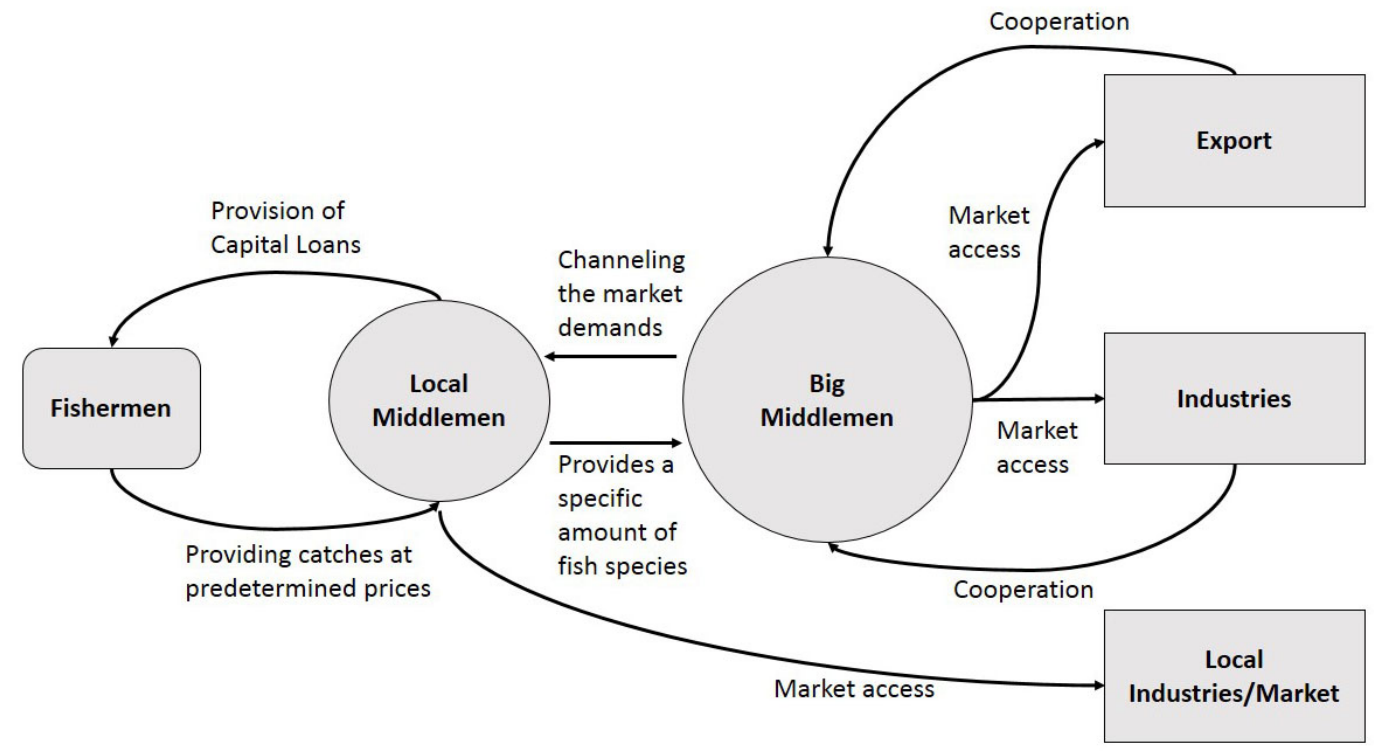

Figure 1: Simplified scheme of small-scale fisheries market chain in most small-scale fishery areas in Indonesia. 


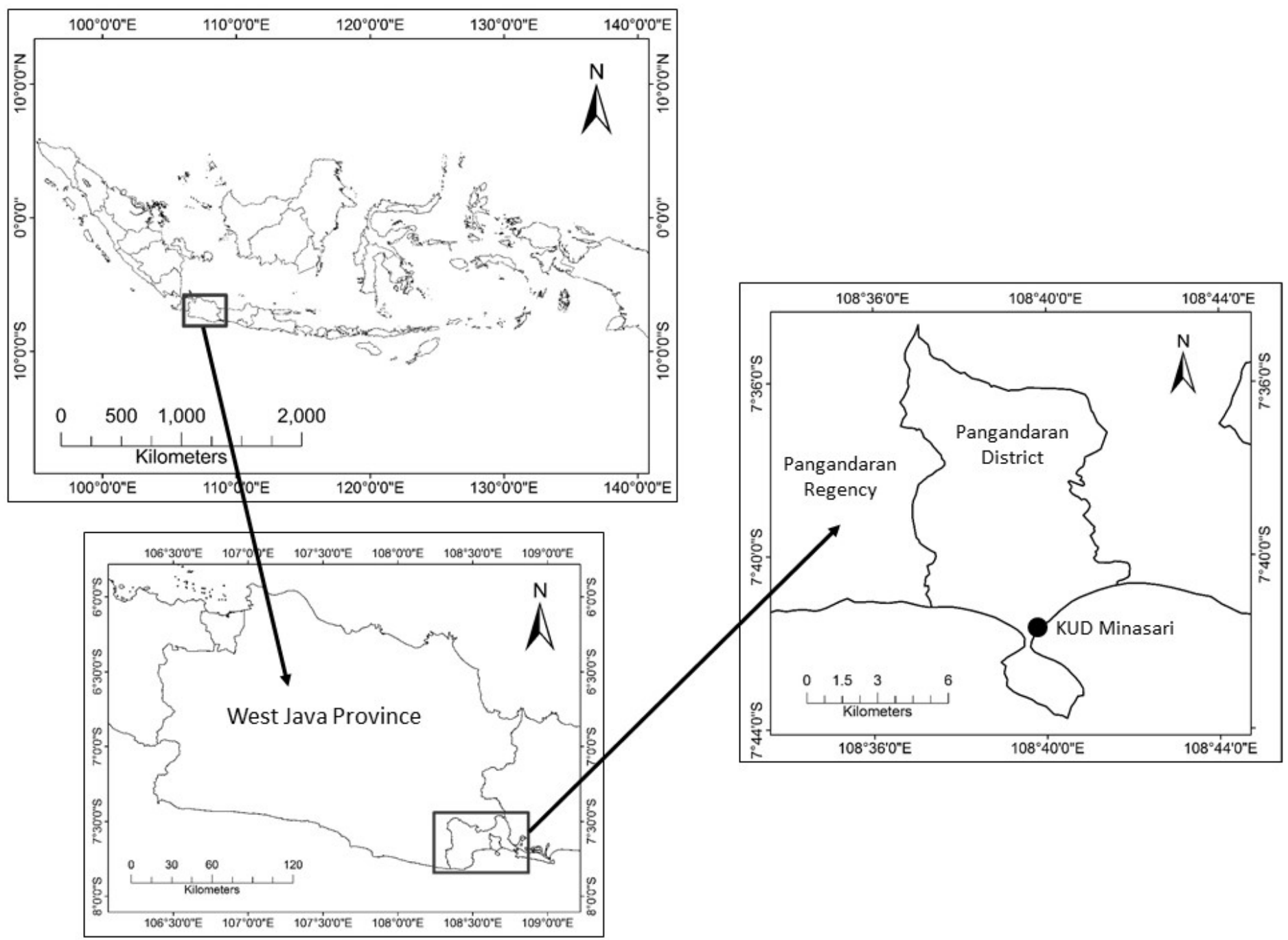

Figure 2: Study area in Pangandaran district. The research was conducted in the main territory of KUD Minasari-a rural enterprise engaged in fishery activities.

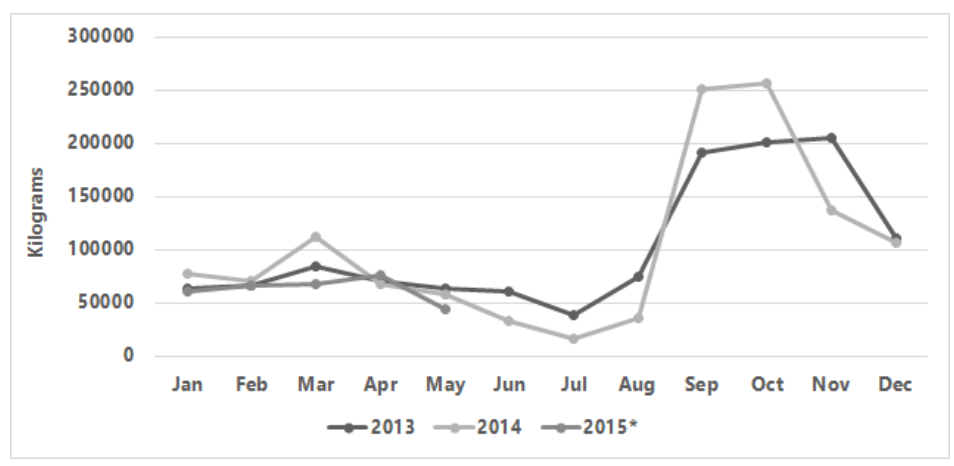

Figure 3: Fish Production in 2013, 2014 and 2015*. Fish production in Pangandaran often decreased in June and started to rise in August until it reached a peak in October. NB: The data for 2015 is only available until May.
In 1977, KPL changed its status to the village cooperative unit Minasari or "Koperasi Unit Desa [KUD] Minasari" in Indonesian [22] with the legal entity number 2074.A/BH/DK-10/24. This change gave institutional benefits for KUD. Upon becoming KUD, they gained legal status as a formal organization and were able to formally collaborate with the government and other institutions. This benefit was used by KUD to collaborate with the government, particularly the marine and fisheries agency, in conducting socialization to the fishermen regarding the importance of being a KUD member. This is the main methods that is still being applied by KUD to attract fishermen. This has not only increased the membership, but also expanded the coverage area of KUD from only two villages [Pangandaran Village and Cijulang Village] at the beginning [in 1977] to two districts at present [Pangandaran District and Sidomulih District].

KUD Minasari has not only targeted fishermen but also middlemen; though in this context, the intended middlemen are local middlemen. This is interesting, considering that the middlemen are potentially 
disadvantaged by the existence of KUD. Although recruiting middlemen to become KUD members is harder than recruiting fishermen, with periodic and intense communication, the middlemen eventually become interested in joining KUD. The existence of middlemen in KUD was simply to ensure that the middlemen obey regulations, though it also minimizes potential conflict between KUD as the new formal trade organization and the middlemen who previously dominated the market through informal trading activities. As members of KUD, middlemen get rights as legal buyers in fish auctions. Furthermore, both fishermen and middlemen have rights to receive financial and non-financial accommodation under certain conditions, such as religious holidays, periods of famine, compensation for the death of a family member, damage to fishing gear and other conditions based on specific needs. The money that funds KUD services is obtained from fish auction activities as members have to deposit $3.5 \%$ of any transaction to KUD.

\subsection{Abandonment of KUD}

In early 2010, there were problems that caused the majority of members-both fishermen and middlemen-to lose trust in KUD. The problems began when the accountability report of KUD officers was rejected by KUD members. The members argued that the management of the KUD was not transparent and presented anomalies. The report submitted contained elements inconsistent with known facts due to the poor services provided by KUD at that time. The member's rights were not granted in certain conditions and there were frauds in weighing fish catches. The officers reasoned that at the time, there was an internal organizational problem which caused obscurity in the capital management and technical implementation of the program. This was exacerbated by the existence of dishonest individuals.

This chaotic situation lasted for around a year. During that time, no trading activity was conducted at fish auctions. This caused all trading activities and fish production in Pangandaran to go unrecorded (see Figure 4), and Pangandaran came to be considered as a fish famine area. However, fish production in Pangandaran remained the same and the fisheries were still running, although trading activities were conducted informally. Fishermen sold their catches to the middlemen and again debts with the middlemen began to arise.

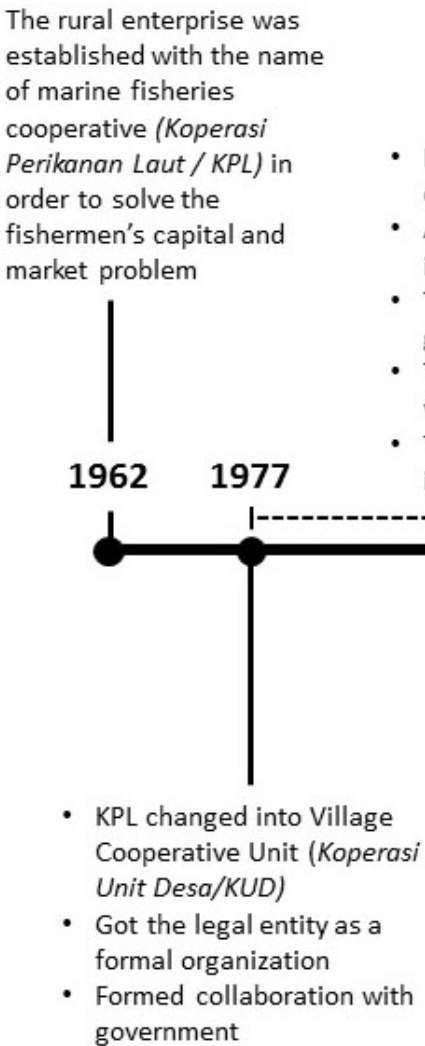

The rural enterprise was established with the name rasi Perikanan Laut / KPL) in ishermen's capital and market problem
- Efforts to restore KUD were started

- New leader was appointed

- Restructuring the organization

- Formed regional commissioner

- Approaching the stakeholders intensively

- Regaining the trust
- Trade activities Guidelines are established (Pangandaran Local Regulation 38/2016 and Mayor Decree 2/2017)

- The majority of fishermen and middlemen are joined KUD

- The value of transactions are stable invited them to join KUD

The number of member were growing

- The business and coverage area were expanding

- Trade activities were institutionalized

2012

- Mismanagement of KUD

- KUD was abandoned

- Trust was diminished

- The number of member were decrease significantly

- Trading activities back to the informal way

- fishermen-middlemen bond started to exist

- Trust was gradually rejuvenated

- KUD's functions were restored

- The value of transactions started to increase rapidly

- Fishermen-middlemen bond were slowly diminished

Figure 4: A simplified timeline of KUD Minasari. Several phases has been experienced by the rural enterprise in managing the fish trade in the Pangandaran District with a brief description in each phase. 
This returned the situation to the time before 1962 when the rural enterprise-KPL at the time-had not yet been established and the market was dominated by middlemen.

Efforts to restore KUD functions began at the end of 2011. Initiated by a man from the local fishermen named Jeje Wiradinata [recent mayor of the Pangandaran Regency], the new KUD management held an extraordinary meeting to discuss a restoration strategy for KUD. The meeting resulted in two general strategies, regaining the trust through guidance for fishermen and middlemen and improving organizational capacity and services of KUD Minasari. KUD collaborated with the marine and fisheries agency in giving intensive socialization and guidance to fishermen and middlemen and also collaborated with the cooperative agency to improve its organizational capacity.

In this phase, KUD returned to a situation similar to its early days of formation. The methods it used were also the same, while the differences were in the size of the present coverage area and its targets. In the early days of KUD, the coverage area was only the Pangandaran coast and it was targeted only at fishermen, whereas in 2010, it had grown to two districts and the targets also included middlemen. This implied that the efforts to regain the trust of the fishermen and middlemen would be harder and more effective than in 1962. To address these challenges, KUD enacted a proactive strategy by maximizing the role of regional commissioners as a fishermen association operating under KUD to intensively communicate with individual fishermen. To support this function, five regional commissioners were placed in charge of the five regions of fishermen in the two districts. Communication between fishermen and KUD was facilitated by regional commissioners in a formal and informal way. Formal meetings were held once every three months or under urgent circumstances, while the fishermen were able communicate informally at any time. The normal procedure was for fishermen to inform KUD of any problems and ask for help. This led to a positive response from KUD by providing a quick service or assistance such as funds in the form of a loan, provision of gear, transportation services or technical assistance.

Different approaches applied to the middlemen. For them, the socialization and counseling was not only to talk about the benefits of being a member of KUD and obeying the administration rules but also the importance of mutual prosperity for both fishermen and middlemen. The approach to the middlemen was also relatively more assertive. KUD often "intimidated" the middlemen by bringing in other middlemen from outside Pangandaran. This threatened the local middlemen who were at risk of losing the fish supply due to the presence of other middlemen. This made the middlemen agree to become KUD members and trade at fish auctions.

A slightly harsh approach did not disrupt communication between the middlemen and KUD. As with the fishermen, communication between KUD and the middlemen was also conducted in formal and informal ways. Both communication methods were also the same with the middlemen. The difference was only the content, as stated above. The problems discussed between the middlemen and
KUD were mostly with regard to price. The middlemen were often dissatisfied with a determined price. The response to this issue was again communication. KUD often invited the fishermen and the middlemen to discuss the current market circumstances or to find the best solution that would be acceptable to both parties. The methods described in this section either to cultivate the trust of the community or to maintain the trust of the members are still being applied to date, despite growth of KUD membership to over 700 and transaction volume to above 35 billion rupiahs [around 2.6 million USD] in the current year.

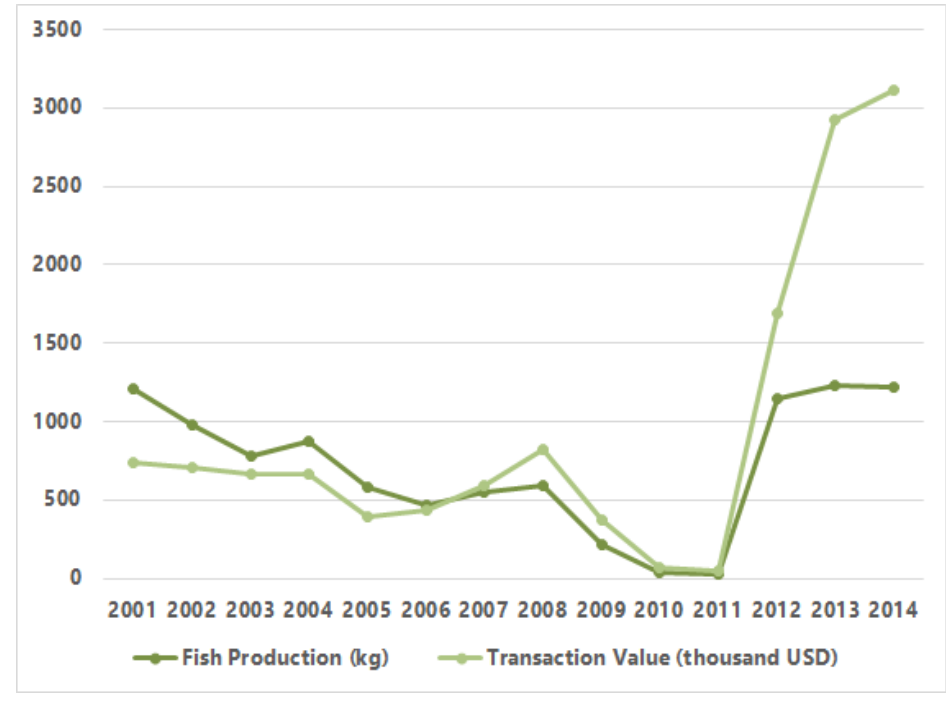

Figure 5: Fish production and the transaction values in Pangandaran Fish Auctions since 2001. Fish production and transaction value data in 2010 and 2011 were decreased because transaction data were not recorded due to the abandonment of KUD. After 2011, since the functions of KUD were restored, the data was well recorded, thus increasing these variables.

\subsection{Current State Condition}

Since 2016, fish trading activities have been strengthened by the legalization of local regulation number 38/2016 in the Pangandaran Regency and mayoral decree number 2/2017. The instigation of these two regulations provides a strong legal basis for KUD in carrying out its functions as a fish trading organization in Pangandaran-despite the fact that government regulation number 54/2002 already exists, encouraging all catches to be sold through fish auctions. From 2016, all fish-trading activities in Pangandaran have been centralized in fish auctions managed by KUD Minasari. The auctions are carried out several times a day, depending on the amount of catches brought in by fishermen. After landing their catches, fishermen must bring them to the fish auction and wait for the auction time. All catches are gathered and placed on the floor based on the species and the ownership of the catches. During the auction process, activities are controlled by a fish auction officer. This is to ensure all trade activities are well-recorded and counted (see Figure 5). 
In this process, the officers act as intermediaries of the price preference from both parties. The officers in charge are provided with knowledge of the current market price. This is to avoid disadvantages to either party.

The prices are determined by the auction process. However, the auction officers set the minimum price limit depending on the amount of the catches supplied and the prevailing market prices. Most fishermen agree that these mechanisms allow them to get better prices because of the competition among buyers in the bidding. However, it also makes prices fluctuate according to the conditions, sometimes causing dissatisfaction from one of the two parties.

The presence of standard regulations in trading activities still does not guarantee zero leakage. Although the majority of trading activities are centralized in the fish auctions, there are still a few fishermen who transact directly with middlemen. The main motive is cliché, they are in debt with the middlemen. Another reason is that the fishermen have a small catch that day, meaning they hesitate to follow the longprocedural rules of the auction. It is faster and simpler for them to trade with the middlemen, even though at a lower price. However, these informal transactions are declining along with the efforts to educate the public about the benefits of the auction mechanism. The majority of fishermen in Pangandaran are now trying to have as little debt as possible with middlemen. They are beginning to consider saving or purchasing easy-to-sell goods for their next fishing funds.

\section{Discussion: Trust in Fisheries Trade Activities}

As explained, the trade circumstances in Pangandaran are achieved through a process. The presence of regulation does not directly guarantee improvements in the management of small-scale fish trade activities, it is proven by many fisheries areas in Indonesia where trading activities are conducted informally through middlemen. Hence, there are non-technical yet non-calculable [23] factors that are influential in the trade formalizing process. Özcan and Bjørnskov [24] have observed that trust is an important variable that can speed up the development process of the region. In the case of Pangandaran, trust acts as a catalyst to institutionalize the market and break the complex fishermen-middlemen bond. Trust is also the reason why fishermen can be gradually convinced and also can maintain a long-term relationship with the rural enterprise [24]. In order to discuss these ideas coherently, this section will be divided into several phases: early establishment phase; expansion phase; abandoned phase; trust rejuvenating phase; and current state phase. A brief explanation of each phase is given in Table 1.

\subsection{Early Formation Phase}

The trust-building process of KUD began with formation. $K P L$, as the origin of KUD, was established by a local fisherman who tried to find a solution to the problems experienced by fishermen in Pangandaran-particularly at that moment. This was very influential in cultivating trust among fishermen, because people tend to trust

Table 1: A brief description of each phase of KUD Minasari.

\begin{tabular}{|c|c|c|}
\hline Year & Phases & Description \\
\hline $1962-1977$ & Early Formation Phase & $\begin{array}{l}\text { - } \\
\text { - } \quad \text { Influenced by interpersonal trust which attached to the similarity of socio-cultural background } \\
\text { - } \quad \text { Relatively easy to gain public trust } \\
\text { - } \quad \text { Limited resources and coverage area } \\
\text { - Informal trade activities still dominating } \\
\text { - The impact was not significant }\end{array}$ \\
\hline $1977-2010$ & Expansion Phase & $\begin{array}{l}\text { - } \quad \text { Rural enterprise turned into a formal institution which was run by more professional employees } \\
\text { - } \quad \text { Public trust was attached with the institution performance } \\
\text { - } \quad \text { Institutional cooperation was established } \\
\text { - The market was gradually institutionalized }\end{array}$ \\
\hline $2010-2011$ & Abandoned Phase & $\begin{array}{l}\text { - The public trust was failed to maintain } \\
\text { - The rural enterprise was abandoned } \\
\text { - Informal activities started to dominate the market } \\
\text { - } \quad \text { Fishermen was gradually bonded with middlemen again }\end{array}$ \\
\hline $2011-2012$ & Trust Rejuvenating Phase & $\begin{array}{l}\text { - The rejuvenating process of institutional trust was catalyzed by interpersonal trust } \\
\text { - The existence of interpersonal trust made the convincing process of fishermen and middlemen easier } \\
\text { - } \quad \text { the organization was restructured in order to improve the services } \\
\text { - The quality of service is important to strengthen the basis of institutional trust } \\
\text { Institutional partners were involved in fostering public trust }\end{array}$ \\
\hline 2012-Present & Current State Phase & $\begin{array}{l}\text { - The trade activities has been formally regulated } \\
\text { - } \quad \text { Fish trade are using auction mechanism } \\
\text { - The fishermen-middlemen bond is not significant, only in a particular circumstances } \\
\text { - Rural enterprise regularly interact with stakeholders in order to maintain the institutional trust. }\end{array}$ \\
\hline
\end{tabular}


other people with whom they interact regularly and have similarities [23], [25] especially in terms of socio-cultural background. The trust linked with the similarity of personal characteristics was necessary to develop a positive behavior towards others in the radius of trust. Sundaramurthy [26], by researching a family company, concluded that the trust which is cultivated among people with the same socio-cultural background is a central feature in the early phase of enterprise. In addition, Guenzi and Georges [27] also reveal that interpersonal trust has a significant impact on a consumer's loyalty. Furthermore, in the context of Pangandaran, the positive response showed by the fishermen in Pangandaran in terms of the existence of KPL indicated optimistic behavior towards KPL. This was proven by the increasing number of fishermen who joined KPL and maintained their relationship over a relatively long period of time. This behavior was developed by the sense of security and confidence towards KPL which was managed by relatives. In other words, the group who established KPL was inside the fishermen's "radius of trust" [25], making trust was easier to cultivate-often developing automatically [23].

\subsection{Expansion Phase}

This phase started in 1977 when the rural enterprise obtained legal status. Prior to this phase, the impact of the rural enterprise was not massive and was limited to a small coverage area due to a lack of resources and reliance on interpersonal relationships with others. As a legal entity, the rural enterprise tuned into a formal institution with a formal organizational structure. This change also shifted the forms of public trust from interpersonal trust into an institutional trust. Besides the legal status of the enterprise, the social distance between KUD and the local community was increased because it was no longer managed by a group of fishermen but by more professional employees. This led to a decrease in interpersonal trust as it was no longer relevant [28]. Forming institutional trust is more difficult because it does not involve a personal emotion or expression but only deals with abstract principles such as the institution's aims and rules [23]. However, in this case, the formation of institutional trust was catalyzed by the interpersonal trust that had already been formed between the fishermen and the embryo of KUD.

The existence of institutional trust was a mandate for KUD to maintain or even to increase. Unlike interpersonal trust, trust in an institution cannot be maintained automatically [29]. It needs strategies and efforts to keep the institutional performance in good condition [25], [29], [30] otherwise the institution will be abandoned. Previous studies have shown that communication plays an important role in reducing the social distance between stakeholders. In the context of companies, communication can eliminate the uncertainty and sustain the interpersonal trust within the company by facilitating people to negotiate and compromise [26], [31]. Furthermore, in a similar context, Sendow, et al [32] stated that communication among stakeholders is an indicator of good public empowerment, particularly in the case of fishermen in Minahasa, Indonesia. The fact that people tend to trust familiar parties, encouraged KUD to increase the intensity of interactions between itself and the fishermen through formal and informal communication. Communication also acted as a medium of consensus and information exchange between KUD and fishermen. This was very important to explain KUD's intentions, form cooperative norms to reduce uncertainties, and increase the fishermen's sense of security by reducing the political and social distance between parties.

\subsection{Abandoned Phase}

The abandonment of KUD in 2010 was primarily caused by the loss of public trust due to mismanagement. This situation has also occurred in several other cases. In 2006, the clinical research community in United States lost public trust due to its failure in terms of ensuring patient safety [33], Stix [34] also revealed that memories of the past banking failure to prevent the financial crisis are causing public distrust towards banks in ten European countries, and Euroscepticism among Belgian citizens is caused by the failure of the EU to give economic benefits to European membership [35]. Although these cases have a different scope and context, they prove that public trust in institution is attached to that institution's performance. Once the performance decreases, then distrust will arise.

In Pangandaran, mismanagement of KUD in 2010 resulted in the degradation of the quality of KUD's services and non-transparency in financial and asset management. This raised public distrust towards the enterprise. Hence, KUD was no longer trusted to run and regulate the fish trade. At that time, the fishermen returned to the middlemen mechanism and the patron-client relationship between fishermen and middlemen was gradually reinstituted. These processes happened quickly; only a few months after the fishermen and middlemen rejected the KUD accountability report, the enterprise was completely abandoned.

\subsection{Trust Rejuvenating and Current State Phase}

Re-cultivation of trust is not an easy process and takes a long time. As stated above, this process deals with some abstract principles [23]. Nevertheless, KUD Minasari has succeeded in rebuilding institutional trust in less than two years. The method used was basically the same as the initial establishment of KUD-KPL at that time. The process was also catalyzed by the interpersonal trust with an individual from among the local fishermen named Jeje Wiradinata who was chairman of KUD at that time. This factor eased KUD management to convince the fishermen. Furthermore, the efforts to re-cultivate institutional trust did not rely on Jeje but also institutional and service improvements, including transparency and accountability of all KUD activities. This was important to increase the performance of KUD as the basis of institutional trust [23].

Another important factor was networking. Networking was an approach applied by KUD order to support its functions. As a legal institution, KUD established relationships with government partners, especially the marine and fisheries agency and the cooperative agency. Bebbington et al [36] states that networks and allies are highly influential in improving stakeholder's abilities to solve problems by escalating the resource mobilization and allocation capabilities. This cooperation allows KUD to mobilize government resources, both human and financial resources, to bolster its programs and improve 
its institutional capacity and effectiveness. These capacity improvements within KUD once again aim to cultivate, maintain or even expand the scope of trust in KUD in Pangandaran. Moreover, KUD has also cooperated with middlemen although in general, the middlemen are the opposite party of the KUD. This is interesting considering that when it was first established, KUD aimed to release fishermen from their bonds to middlemen. The cooperation allows a positive role for middlemen to be remain in place, specifically as intermediaries between the market and the fishermen [8], [16]. Furthermore, after trust was rejuvenated, the KUD's function as a regulator of fish trade was restored. In this phase, the fishermenmiddlemen bond was gradually diminished due to the effective function of KUD in ensuring both parties benefit from the trade activities. Fish production is well recorded with a significant increase in average prices (see Table 2).

\subsection{Lessons Learned from Pangandaran}

This paper emphasizes the process of rural enterprise in solving fisheries trade problems in the Pangandaran District. The patronclient relationship between fishermen and middlemen is just an example of a common issue in fishermen communities, particularly in developing countries. As a marginalized community [1], fishermen have become a target of various policies which aim to improve their welfare from various approaches. Unfortunately, those policies often fail to solve the problem due to lack of support from the community and poor socio-economic understanding from the government. Various studies have addressed these issues both in Indonesia and in other countries. In Indonesia, cases from Gorontalo [37], Semarang [38], and even Pangandaran [39] reveal that government policies failed to make a significant impact on fishermen due to a mismatch between the assistance and the needs. Similar issues also occurred in the Philippines [40] and Texas [41] when the policies did not get political support from fishermen because they was considered unable to solve the problems in question.

The case of Pangandaran shows that to solve a particular problem, it takes an appropriate approach that can cultivate public trust in a policy or an institution. In this phase, interpersonal trust is needed in order to catalyze the process, or otherwise extra effort is needed to convince the public of the institution's accountability and capability. Furthermore, public trust will bring political support and positive behavior to the institution or policies. In addition, an understanding regarding socio-economic conditions is the first important step in initiating policy implementation. Prior studies [26], [31], [32], [37]-
[41] have revealed the importance of socio-economic understanding in order to define the problem and determine a suitable approach.

\section{Conclusion}

This paper has found that there are non-technical and non-calculable variables which are very influential in institutionalizing the market, particularly the market of small-scale fisheries. Trade institutionalizing processes in Pangandaran are catalyzed by a personal dimension variable named trust. The research revealed that trust in rural enterprise as an institution is the main factor that simplifies the trade institutionalizing process in Pangandaran. Both interpersonal trust and institutional trust have their own role in cultivating general trust in Pangandaran. Interpersonal trust was very influential in the initial process of establishing the rural enterprise due to its strongly embedded characteristics which were caused by similarity of background and familiarity [23], [30]. On the other hand, institutional trust is important in the running of the institution because it facilitates the institution in carrying out its role by increasing public compliance with rules and regulations [23]. This study is restricted to exploring the general success of KUD in Pangandaran in its role to cut the patron-client connection between middlemen and fishermen. This study does not give a "one-for-all" solution for all similar problems. Instead, it has identified important factors that can enhance the success of KUD within the special characteristics of its location.

More research is needed to understand the aspects of sociology and political ecology in the context of the fish market in Indonesia in general, and specifically in Pangandaran. SNA (social network analysis) and political stakeholder analysis of the middlemen in general is needed in order to understand the role of middlemen regarding this study. Furthermore, an ethnographic approach to middlemen and fishermen is needed to be able to fully understand the relationship between the two groups in the context of fisheries resources.

\section{References}

[1] E. H. Allison and F. Ellis, "The livelihoods approach and management of smallscale fisheries," Mar. Policy, vol. 25, no. 5, pp. 377-388, Sep. 2001. Doi: https://doi. org/10.1016/s0308-597x(01)00023-9

[2] S. Solaymani and F. Kari, "Poverty evaluation in the Malaysian fishery community," Ocean Coast. Manage., vol. 95, pp. 165-175, Jul. 2014. Doi: https://doi.org/10.1016/j.

Table 2: Paired t test analysis using average price data (total transaction value divided by total production) in Pangandaran fish auctions before trust rejuvenation phase (2004-2009) and after the trust rejuvenation phase (2011-2014). 2010 data is not included because the transactions at that time were not recorded properly due to the abandonment of KUD. The analysis shows that, at a $95 \%$ confidence level, the trust rejuvenation process had an impact on the increase in the average transaction value in Pangandaran $($ sig. $<0,05)$.

\begin{tabular}{|c|c|c|c|c|c|c|c|c|}
\hline & & \multicolumn{5}{|c|}{ Paired Differences } & \multirow{3}{*}{ t-value } & \multirow{3}{*}{$\begin{array}{c}\text { Sig. } \\
\text { (2-tailed) }\end{array}$} \\
\hline & & \multirow{2}{*}{$\begin{array}{c}\text { Average differences } \\
\text { (mean) }\end{array}$} & \multirow{2}{*}{ Std. Deviation } & \multirow{2}{*}{ Std. Error Mean } & \multicolumn{2}{|c|}{$95 \%$ Confidence Interval } & & \\
\hline & & & & & Lower & Upper & & \\
\hline Pair 1 & $\begin{array}{l}\text { Before Trust Rejuvenating - } \\
\text { After Trust Rejuvenating }\end{array}$ & $-953,50236$ & 323,27751 & 161,63876 & $-1467,90902$ & $-439,0957$ & $-5,899$ & 0,01 \\
\hline
\end{tabular}




\section{ocecoaman.2014.04.017}

[3] I. S. Wekke and A. Cahaya, "Fishermen poverty and survival strategy: Research on poor households in Bone Indonesia," Procedia Economics and Finance, vol. 26, pp. 7-11, Jan. 2015. Doi: https://doi.org/10.1016/s2212-5671(15)00962-4

[4] M. Knudsen, "Poverty and beyond: Small-scale fishing in overexploited marine environments," Hum. Ecol., vol. 44, no. 3, pp. 341-352, Jun. 2016. Doi: https://doi. org/10.1007/s10745-016-9824-y

[5] Y. U. Oladimeji, M. A. Damisa, Z. Abdulsalam, and D. F. Omokora, "A micro level analysis of poverty among artinasal rural fishery in Kwara State, Nigeria," Ethiop. J. Environ. Stud. Manag., vol. 7, no. 4, pp. 423-433, 2014. Doi: ttps://doi.org/10.4314/ ejesm.v7i4.9

[6] M. G. Kularatne, U. S. Amarasinghe, P. Wattage, and S. S. D. Silva, "Evaluation of community participation for the development of culture-based fisheries in village reservoirs of Sri Lanka," Aquacult. Econ. Manag., vol. 13, no. 1, pp. 22-38, Feb. 2009. Doi: https://doi.org/10.1080/13657300802674914

[7] E. T. Lawson, C. Gordon, and W. Schluchter, "The dynamics of poverty-environment linkages in the coastal zone of Ghana," Ocean Coast. Manage., vol. 67, pp. 30-38, Oct. 2012. Doi: https://doi.org/10.1016/j.ocecoaman.2012.05.023

[8] B. Crona, M. Nyström, C. Folke, and N. Jiddawi, "Middlemen, a critical socialecological link in coastal communities of Kenya and Zanzibar," Mar. Policy, vol. 34, no. 4, pp. 761-771, Jul. 2010. Doi: https://doi.org/10.1016/j.marpol.2010.01.023

[9] A. Cahaya, "Fishermen community in the coastal area: A note from Indonesian poor family," Procedia Economics and Finance, vol. 26, pp. 29-33, Jan. 2015. Doi: https://doi.org/10.1016/s2212-5671(15)00801-1

[10] A. G. Merlijn, "The role of middlemen in small-scale fisheries: A case study of Sarawak, Malaysia," Dev. Change, vol. 20, no. 4, pp. 683-700, Oct. 1989. Doi: https://doi.org/10.1111/j.1467-7660.1989.tb00362.x

[11] R. S. Pomeroy and F. Berkes, "Two to tango: The role of government in fisheries co-management," Mar. Policy, vol. 21, no. 5, pp. 465-480, Sep. 1997. Doi: https:// doi.org/10.1016/s0308-597x(97)00017-1

[12] S. Kininmonth, B. Crona, Ö. Bodin, I. Vaccaro, L. Chapman, and C. Chapman, "Microeconomic relationships between and among fishers and traders influence the ability to respond to social-ecological changes in a small-scale fishery," Ecol. Soc., vol. 22, no. 2, May 2017. Doi: https://doi.org/10.5751/es-08833-220226

[13] R. J. Stanford, B. Wiryawan, D. G. Bengen, R. Febriamansyah, and J. Haluan, "Exploring fisheries dependency and its relationship to poverty: A case study of West Sumatra, Indonesia," Ocean Coast. Manage., vol. 84, pp. 140-152, Nov. 2013. Doi: https://doi.org/10.1016/j.ocecoaman.2013.08.010

[14] Se Tin, "Analisis pendapatan dan beban nelayan di pantai Pangandaran 2004," Jurnal Akuntansi Maranatha, vol. 3, no. 2, pp. 44-56, Dec. 2014.

[15] H. Wawansyah, I. Gumilar, and A. Taofiqurohman, "Kontribusi ekonomi produktif wanita nelayan terhadap pendapatan keluarga nelayan," Jurnal Perikanan Kelautan., vol. 3, no. 3, Sep. 2012.

[16] D. Ferrol-Schulte, S. C. A. Ferse, and M. Glaser, "Patron-client relationships, livelihoods and natural resource management in tropical coastal communities," Ocean Coast. Manage., vol. 100, pp. 63-73, Nov. 2014. Doi: https://doi.org/10.1016/j. ocecoaman.2014.07.016

[17] M. Bailey, S. Bush, P. Oosterveer, and L. Larastiti, "Fishers, fair trade, and finding middle ground," Fish. Res., vol. 182, pp. 59-68, Oct. 2016. Doi: https://doi. org/10.1016/j.fishres.2015.11.027

[18] C. Pedroza, "Middlemen, informal trading and its linkages with IUU fishing activities in the port of Progreso, Mexico," Mar. Policy, vol. 39, pp. 135-143, May 2013. Doi: https://doi.org/10.1016/j.marpol.2012.10.011

[19] E. Lubis and A. B. Pane, "An optimum model of fish auction in indonesian fishing ports in accordance with the characteristics of fisherman," Journal of Coastal Development, vol. 15, no. 3, pp. 282-296, Sep. 2012.
[20] D. S. Adhuri, L. Rachmawati, H. Sofyanto, and N. Hamilton-Hart, "Green market for small people: Markets and opportunities for upgrading in small-scale fisheries in Indonesia," Mar. Policy, vol. 63, pp. 198-205, Jan. 2016. Doi: https://doi. org/10.1016/j.marpol.2015.03.021

[21] H. Wibisono and A. Rosyidie, "Fisheries and tourism integration: Potential and challenges in Pangandaran village," in Proc. of 7th Rural and Regional Research Group International Conference, Johor Bahru, Malaysia, 2016, pp. 367-374.

[22] A. Malawat, "Strategi pengembangan usaha KUD Minasari di kecamatan Pangandaran, Kabupaten Ciamis provinsi Jawa Barat," Institut Pertanian Bogor, 2008.

[23] D. Khodyakov, "Trust as a process: A three-dimensional approach," Sociology, vol. 41, no. 1, pp. 115-132, Feb. 2007. Doi: https://doi.org/10.1177/0038038507072285

[24] B. Özcan and C. Bjørnskov, "Social trust and human development," The Journal of Socio-Economics, vol. 40, no. 6, pp. 753-762, Dec. 2011. Doi: https://doi. org/10.1016/j.socec.2011.08.007

[25] F. Fukuyama, "Social capital and the global economy," Foreign Aff., vol. 74, no. 5, pp. 89-103, 1995. Doi: https://doi.org/10.2307/20047302

[26] C. Sundaramurthy, "Sustaining trust within family businesses," Fam. Bus. Rev., vol. 21, no. 1, pp. 89-102, Mar. 2008. Doi: https://doi.org/10.1111/j.17416248.2007.00110.x

[27] P. Guenzi and L. Georges, "Interpersonal trust in commercial relationships: Antecedents and consequences of customer trust in the salesperson," Eur. J. Marketing, vol. 44, no. 1/2, pp. 114-138, Feb. 2010. Doi: https://doi. org/10.1108/03090561011008637

[28] A. Etang, D. Fielding, and S. Knowles, "Does trust extend beyond the village? Experimental trust and social distance in Cameroon," Exp. Econ., vol. 14, no. 1, pp. 15-35, Mar. 2011. Doi: https://doi.org/10.1007/s10683-010-9255-3

[29] K. Yang, "Trust and citizen involvement decisions," Admin. Soc., Nov. 2006. Doi: https://doi.org/10.1177/0095399706292095

[30] R. D. Putnam, "Bowling alone: America's declining social capital," in Culture and Politics, Palgrave Macmillan, New York, 2000, pp. 223-234. Doi: https://doi. org/10.1007/978-1-349-62397-6 12

[31] E. Lau and S. Rowlinson, "Interpersonal trust and inter-firm trust in construction projects," Construction Management and Economics., vol. 27, no. 6, pp. 539-554, Jun. 2009. Doi: https://doi.org/10.1080/01446190903003886

[32] G. Sendow, J. Lapian and A. Tumbel "The strategic role of human resources and empowerment through the commitment of the government in alleviating poverty on fishermen society coastal of south Minahasa district Indonesia," J. Res. Bus. Econ. Manage., vol. 7, no. 1, pp. 1062-1068, Sep. 2016.

[33] K. A. Getz, "Getting to the heart of public distrust," Appl. Clin. Trials, vol. 17, no. 9, pp. 38-42, Sep. 2008.

[34] H. Stix, "Why do people save in cash? Distrust, memories of banking crises, weak institutions and dollarization," J. Bank. Finance, vol. 37, no. 11, pp. 4087-4106, Nov. 2013. Doi: https://doi.org/10.1016/j.jbankfin.2013.07.015

[35] K. Abts, D. Heerwegh, and M. Swyngedouw, "Sources of Euroscepticism: Utilitarian Interest, Social Distrust, National Identity and Institutional Distrust," World Political Science, vol. 5, no. 1, Jan. 2009. Doi: https://doi.org/10.2202/1935-6226.1057

[36] A. Bebbington, L. Dharmawan, E. Fahmi, and S. Guggenheim, "Local capacity, village governance, and the political economy of rural development in Indonesia," World Dev., vol. 34, no. 11, pp. 1958-1976, Nov. 2006. Doi: https://doi.org/10.1016/j. worlddev.2005.11.025

[37] S. Kamuli, "Dampak implementasi kebijakan taksi mina bahari pada produktivitas nelayan tradisional," Jurnal Ilmu Administrasi Negara, vol. 12, no. 1, pp. 1-73, Jul. 2012.

[38] B. Setioko, E. E. Pandelaki, and T. W. Murtini, "Towards sustainable urban growth: The unaffected fisherman settlement setting (with case study semarang coastal 
area)," Procedia Environmental Sciences, vol. 17, pp. 401-407, Jan. 2013. Doi: https://doi.org/10.1016/j.proenv.2013.02.053

[39] I. Sartika, "Evaluasi kebijakan pemberdayaan nelayan," Jurnal Ilmu Administrasi Negara, vol. 11, no. 02, Jul. 2011.

[40] A. Hatcher, S. Jaffry, O. Thébaud, and E. Bennett, "Normative and social influences affecting compliance with fishery regulations," Land Econ., vol. 76, no. 3, pp. 448461, 2000. Doi: https://doi.org/10.2307/3147040

[41] R. N. Johnson and G. D. Libecap, "Contracting problems and regulation: The case of the fishery," The American Economic Review, vol. 72, no. 5, pp. 1005-1022, Dec. 1982. 